\title{
FISHING ACTIVITIES AND FISHERMEN INCOME IN RANAU LAKE, SOUTH SUMATRA
}

\author{
Dina Muthmainnah', Subagdja1, Makri', Dwi Atminarso' ${ }^{1}$ and Safran Makmur ${ }^{1}$ \\ ${ }^{1}$ Research Institute for Inland Fisheries, Palembang \\ Received; April 20-2015 Received in revised from June 10-2015; Accepted June 15-2015 \\ e-mail: dina.gofar@yahoo.co.id
}

\begin{abstract}
Fish resources contribute to the socio-economic development for people who live surrounding the waters. The fishermen of Ranau Lake, South Ogan Komering Ulu Regency, South Sumatra Province and West Lampung Regency, Lampung Province are the prime stakeholder with direct interest in fish resources, because they depend on it for their livelihoods or they are directly involved in its exploitation in some ways. However, to well manage these resources, it needs data and information about fish utilization and fishing activity. The objectives of this work are to assess fishing activities such as the fishing boat and gears, catch composition, fish yield, catch per unit of effort (CPUE) and to estimate the fihermen income with economical parameter such as cost and price. Field surveys were conducted from February to November 2014. Fishing activities data were collected from field survey and interview. The results showed that fish resources utilization in Ranau Lake was categorized as traditional and small scale fisheries using different selective fishing gears such gillnet, harpoon, net trap and basket trap with the fish catch in average of 696.66 g/day; $205.03 \mathrm{~g} /$ day; $1.584 .06 \mathrm{~g} /$ day and $123.67 \mathrm{~g} /$ day, respectively. Fisherman income (IDR $2,163,300)$ means the fishermen in Ranau Lake reach standard Indonesian welfare.
\end{abstract}

\section{KEYWORDS: Fishery activity, fish biodiversity, Ranau Lake}

\section{INTRODUCTION}

The livelihoods of many small-scale fishing communities that directly depend on fisheries are vulnerable to poverty. Like most developing countries, fisheries have been observed as a result of lack of alternative livelihoods). In developing countries such as in Ghana, fishery resources are under pressure due to high demand for fishery products, poverty but the population grow highly and particularly lack of alternative livelihood options (Asiedu \& Nunoo, 2013). In Indonesia, small-scale fisheries also are practiced in many inland waters areas, for example was found in Ranau Lake.

Ranau Lake is important in supporting the socioeconomic need of the people in the surrounding areas. Fisheries activities in Ranau Lake consist of capture fisheries and aquaculture. Fishing activity in Ranau Lake is vital in creating employment opportunities, particularly for low-income families in rural areas where job opportunities and options are limited. In addition to fisheries, Ranau lake is utilized by other sectors such as agriculture and tourisms. Some irrigation dam were constructed at the outlet of Ranau lake for agricultural purposes. The activities of fisheries, agriculture and tourisms could influence the sustainability of aquatic resources of this lake. Frequent death mass of both wild and fish cage, will decrease number of fish catch and water quality of Ranau lake, and this have been recorded since 1995.
These phenomenon would influence Ranau lake aquatic resources in the long run.

Several studies such as fishing gears (Gaffar \& Utomo, 1991), fish biodiversity (Samuel et al., 2010) and fisheries management of hampala barb (Hampala macrolepidota) (Makmur et al., 2014), had been conducted in Ranau Lake. However, there are still limited information from scientific literature on livelihood such as the income of fishers surrounding Ranau Lake. While the information have significant role for management of fish and aquatic resources in the area.

The objectives of this work are to assess fishing activities including the fishing boat boats and gears, catch composition, fish yield, catch per unit of effort (CPUE) and the income of the fishermen with parameter cost and price. These information are one of components needed to formulate a management plan to optimise fish production whilts enhance sustainable fish yield of the Lake. Thus, it will support livehood and protein need for local people's family as small scale fishermen.

\section{MATERIALS AND METHODS Study Site}

Ranau Lake, the second largest lake in Sumatra after Toba Lake, is located in South Ogan Komering Ulu and Tulang Bawang Regency. Ranau Lake, 
geographically within $103^{\circ} 48^{\prime} 30^{\prime \prime}-103^{\circ} 55^{\prime} 50^{\prime \prime} E$ and $4^{\circ} 46^{\prime} 25^{\prime \prime}-4^{\circ} 51^{\prime} 45^{\prime \prime} S$ (Fugure 1), covers about 12,800 hectares area with $16 \mathrm{~km}$ shoreline, $8 \mathrm{~km}$ wide, altitude of $540 \mathrm{~m}$ above sea level surrounded by mountainous forest (Sulastri et al., 1999), and inhabited by many species of freshwater fish.

\section{Fish Samples}

Fish sampling were carried out by eight periodical sampling scheme along year of 2014 at two stations: Talang Teluk Village and Banding Agung Village, located on Ranau Lake, South Ogan Komering Ulu
Regency, South Sumatra Province (Figure 1). Fish catch data were collected from collaborated fishermen, sampled by various kinds of fishing gears (gillnet, harpoon, net trap and basket trap). Species composition was found by gill net fishing experimental using at various mesh size. Identification for fish was conducted in the laboratory of Research Institute for Inland Fisheries, Palembang. The fish were preserved in $10 \%$ formalin solution and transferred to the laboratory. Identification was carried out by meristic and morphological observation using reference books (Kottelat et al., 1993; Weber \& de Beaufort, 1931).

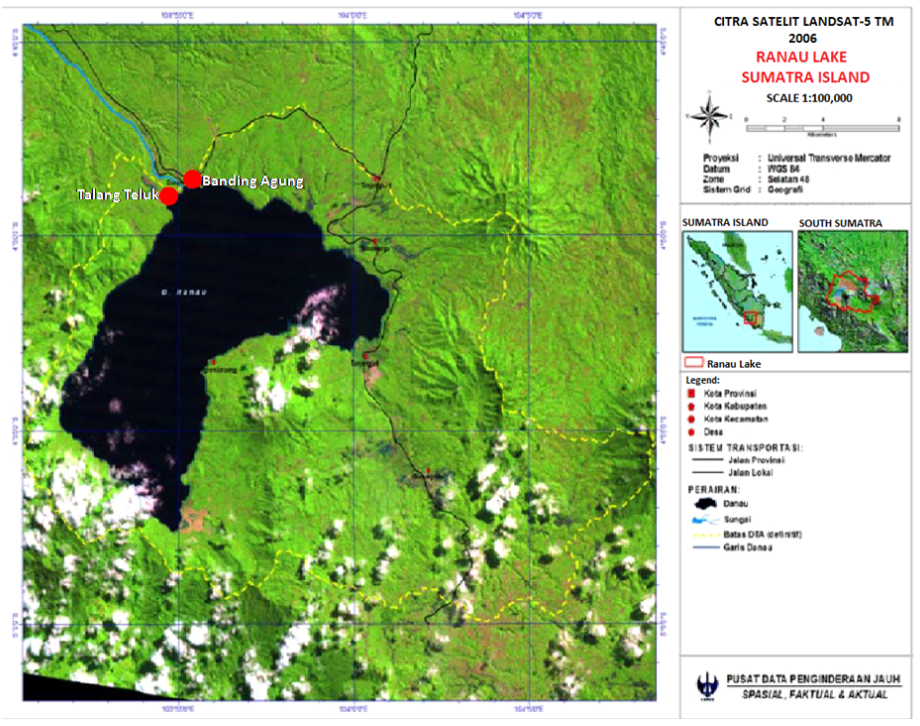

Figure 1. Study site in Ranau Lake.

\section{Fishing Activity}

Fishing activities data relate to the fishermen income such as 1) number of fishermen, 2) fishing gears, 3) total of fish caught per species per fishing gears per year, 4) fish price, and 5) operational budget were collected from direct interview using questioner sheet to 10-years experienced fishermen and fish traders. The number of respondent interviewed from Banding Agung and Talang Teluk villages was 16 and 11 respondents, respectively.

\section{Data Analysis}

The average CPUE was determined in 2014. Population density of fish was estimated using CPUE and total annual fishing gears effort. The total catch was calculated using the equation $\mathrm{Ct}=\mathrm{f}(\mathrm{ct} / \mathrm{ft}$ ) (Skurdal et al., 1994). Where Ct is the total catch and $f$ is the total annual catch effort, while ct/ft is the catch per unit effort defined as gram of fish per fishing gear per day (g/gear/day).
The income of fisherman was collected through questionnaire administered to each of the dependent fishermen. In the this study, the income of the fishermen only containing the fishing income and the expenditure account of fishing, like buying boat, nets and construction of fishing devices, were deducted from the fishing income. Therefore, the income of the fisherman is considered as net income (Deka et al., 2001).

\section{RESULTS AND DISCUSSION}

\section{Results \\ Fishing Activities}

There are four types of fishing gears used in Ranau Lake where gillnet is the most dominant gear used by fishermen. The others are harpoon, basket trap and traditional fish aaggregating device (FAD) locally named as kucuan. During 2014, the fishing gears caught different type of fish and different total fish catch (Table 1). Out of four fishing gears operated, gillnet caught more fish than the other fishing gears. 
Table 1. Fishing gear, species caught and total catch during 2014

\begin{tabular}{lllc}
\hline No. & Fishing Gear & \multicolumn{1}{c}{ Species Caught } & $\begin{array}{c}\text { Total catch } \\
\text { (kg) }\end{array}$ \\
\hline 1. & Gillnet & $\begin{array}{l}\text { Oreochromis mossambicus, Hampala macrolepidota, } \\
\text { Pristolepis grooti, Osteochilus vittatus, Oreochromis } \\
\text { niloticus, Puntius sp, Cyclocheilichthys armatus, } \\
\text { Hemibagrus nemurus, Puntigrus tetrazona, Cyprinus }\end{array}$ & $167,197.80$ \\
carpio, Notopterus notopterus, Channa striata, \\
Mastacembelus sp, Pteryoplichthys pardalis, Rasbora sp, \\
Puntius javanicus, Tor sp \\
2.
\end{tabular}

The description for each fishing gears and its fish yield described below:

\section{Gillnet}

Gillnet is a passive gear with several mesh size ranging from $1.25-3.5$ inch, length ranging from 100 to $200 \mathrm{~m}$ with depth around 2.5 to $5 \mathrm{~m}$. It sets in and hauls twice a day, for $6-8$ hours, at night time and day time, using un-motorized boat.

The gillnet can be used for one year and commonly captures Indonesian leaffish, hampala barb, mozambique tilapia, asian redtail fish, bonylip barb, fronze featherback, or nile tilapia (Table 2). Indonesian

Table 2. Fish caught by gillnet in 2014 leaffish and hampala barb are the main species by this fishing gear.

\section{Harpoon}

It is a traditional and simple fishing gear, an individual gear made from wood stick with iron tip and length of 1.5 meters. For catching target fish, fishermen should dive for 2 to 3 minutes in water of 7 - $10 \mathrm{~m}$ depth, one to two hours per day, wait for the big fish passing and driving a spear into the body, so the fish will be scars on his body. Water conditions should be clear for easy operation of this fishing gear, on the littoral zone around 0 to $100 \mathrm{~m}$ from coastline. The fish caught usually Mozambique tilapia or economic large fish such as Oreochromis mossambicus (Table 3 ).

\begin{tabular}{lllll}
\hline \multirow{2}{*}{ No. } & \multicolumn{2}{c}{ Local Name/Species/Common Name } & \multicolumn{3}{c}{ Fish yield per year } \\
\cline { 3 - 5 } & & $\mathbf{N}$ & $\begin{array}{c}\text { Total weight } \\
\mathbf{( k g )}\end{array}$ & Percentage \\
\hline 1 & Mujaer/Oreochromis mossambicus/Mozambique tilapia & 175 & $16,446.50$ & 9.84 \\
2 & Arongan/Hampala macrolepidota/Hampala barb & 886 & $59,680.20$ & 35.69 \\
3 & Kepor/Pristolepis grooti/Indonesian leaffish & 1,400 & $63,840.34$ & 38.18 \\
4 & Palau/Osteochilus vittatus/Bonylip barb & 66 & $3,749.58$ & 2.24 \\
5 & Nila/Oreochromis niloticus/Nile tilapia & 22 & $1,526.80$ & 0.91 \\
6 & Selibak/Puntius sp & 263 & $9,870.20$ & 5.90 \\
7 & Keperas/Cyclocheilichthys armatus & 17 & 780.13 & 0.47 \\
8 & Baung/Hemibagrus nemurus/Asian redtail catfish & 94 & $8,066.14$ & 4.82 \\
9 & Ikan aji/Puntigrus tetrazona/ Sumatra barb & 398 & 371.14 & 0.22 \\
10 & Mas/Cyprinus carpio/Common carp & 9 & $1,073.90$ & 0.64 \\
11 & Putak/Notopterus notopterus/Fronze Featherback & 5 & 244.98 & 0.15 \\
12 & Gabus/Channa striata/Stripped Snakehead & 1 & 260.10 & 0.16 \\
13 & Tilan/Mastacembelus sp & 3 & 403.2 & 0.24 \\
14 & Sapu jagad/Pteryoplichthys pardalis & 1 & 23.87 & 0.01 \\
15 & Seluang/Rasbora sp/Rasbora & 8 & 85.36 & 0.05 \\
16 & Tawes/Puntius javanicus/Silver barb & 4 & 586.36 & 0.35 \\
17 & Semah/Tor sp/Mahseer & 1 & 189.00 & 0.11 \\
\hline
\end{tabular}


Table 3. Fish caught by harpoon in 2014

\begin{tabular}{|c|c|c|c|}
\hline \multirow{2}{*}{ No. } & \multirow{2}{*}{ Local Name/Species/Common Name } & \multicolumn{2}{|c|}{ Fish yield per year } \\
\hline & & $\mathbf{N}$ & Total weight (kg) \\
\hline 1 & $\begin{array}{l}\text { Mujaer/Oreochromis } \\
\text { mossambicus/Mozambique tilapia }\end{array}$ & 9 & $13,901.79$ \\
\hline 2 & Keperas/Cyclocheilichthys armatus & 4 & $4,250.00$ \\
\hline 3 & $\begin{array}{l}\text { Putak/Notopterus notopterus/Fronze } \\
\text { Featherback }\end{array}$ & 2 & 870.90 \\
\hline 4 & Tilan/Mastacembelus sp & 3 & 660.30 \\
\hline
\end{tabular}

\section{Fish Aggregating Device /FAD (Kucuan)}

Kucuan is categorized as fish agregating device made from 2,5 m-encircled series bamboo split with the bottom side is opened about $20-30 \mathrm{~cm}$ from the river surface sediment. The atrractor used usually is aquatic macrophytes (Hydrilla verticillata) placed at the bottom and on the top of kucuan is covered by cinnamon leaves. This FAD is set in area with water depth around 2 meters and set in the crescent for 6 to 8 hours with the target fish is only the spawn bonylip barb (Osteochilus vittatus). Gill net will encircle the FAD if there is water splashing resulting of bonylip barb mating activities. This mating bonylip barbs are collected by pulling the FAD and its encircled gill net to the river shore. This fishing activitiy caugh 198 individuals fish with their total weight of $19,008.67 \mathrm{~kg} /$ year.

\section{Basket trap}

Basket trap, a passive gear made from bamboo split, is usually used to catch bottom fish and catfish.
The basket traps length is vary from $40 \mathrm{~cm}$ to $1 \mathrm{~m}$ depending on the depth of waters. The trap has to set with its mouth according to current direction to force the fish with swept current on to trap. This gear is very effective in capturing nearly all fish moving to the downstream. The target fish for this fishing gears is only catfish (Clarias sp), caught 24 individuals fish with total weight 2,968.08 kg/year.

\section{CPUE}

Catch per unit effort (CPUE) was defined in this study as grams of fish per day for each fishing gear. Net trap (FAD) has the highest CPUE but this gear operated only in several days of the year (Table 4).

\section{Income of Individual Fisherman}

According to the local prices, the fish could be grouped into three levels, the cheap fish is less than IDR $15,000 / \mathrm{kg}$ of the average price, the medium price fish is IDR 15,000 to 40,000 , and the high price is more than IDR 40,000 like tilapia and carp (Table 5).

Table 4. Catch per unit effort of each fishing gear on 2014 in Ranau Lake

\begin{tabular}{llc}
\hline No. & Fishing gear & Catch per unit effort (gram/day) \\
\hline 1. & Gillnet & 696.66 \\
2. & Harpoon & 205.03 \\
3. & FAD (Kucuan) & $1,584.06$ \\
4. & Basket Trap & 123.67 \\
\hline
\end{tabular}

Table 5. Average price of fish, cost for boat and fishing gears in Ranau Lake

\begin{tabular}{clccc}
\hline No. & Fishing Gear & $\begin{array}{c}\text { Average Price in } \\
\text { Fish (IDR) }\end{array}$ & Cost for Boat (IDR) & $\begin{array}{c}\text { Cost for Fishing Gear } \\
\text { (IDR) }\end{array}$ \\
\hline 1. & Gillnet & 30,000 & $2,500,000$ & 150,000 \\
2. & Harpoon & 40,000 & - & 25,000 \\
3. & FAD (Kucuan) & 10,000 & - & 30,000 \\
4. & Basket Trap & 25,000 & - & 25,000 \\
\hline
\end{tabular}


Operating cost of the gillnet was higher than other fishing gears. It related to the price of nets and engine fuel of boat. The main operating cost is purchase of boat and fishing gears. Within an month the active fishing days for gill net, harpoon, FAD and basket trap is commonly around 20 days, eight days, six days and four days respectively, and only gill net and harpoon used in whole year. Fish agregating device and basket trap are operated only two and six months a year. Each fisherman has 5-15 piece gillnets, one harpoon, and 10-20 basket traps. Fish agregating device is operated only by certain fishermen. Some groups of fishermen operated three to five FADs during the first two months of the rainy season. Based on this operating cost and total fish catch, the total income per month is IDR 2,163,344/fisherman. The highest contribution to each fisherman income is derived from the gill net $(91,14 \%)$ (Table 6$)$.

Tabel 6. Income per fisherman in Ranau Lake

\begin{tabular}{lll}
\hline No. & Fishing Gear & Income (IDR) \\
\hline 1. & Gillnet & $1,971,612$ \\
2. & Harpoon & 63,527 \\
3. & FAD (Kucuan) & 66,703 \\
4. & Basket Trap & 61,503 \\
\hline & Total Income (IDR) & $2,163,344$ \\
\hline
\end{tabular}

\section{Discussion}

Most of fishing gears operated by the fishermen in this study is almost similar with the fishing gears used by the fishermen reported by Gaffar \& Utomo (1991). Fishermen commonly work individually using several fishing gears such as gillnet, drift net, pole and line, long line, and harpoon. However, current study found a fishing activy by using FAD (kucuan) is applied by certain fishermen group in Ranau Lake. This fishing activity threaten bonylip barb population in the long run since its main target is spawn bonlip barbs.

Gillnet is the most dominant gear used by fishermen in this study due this fishing gear was the most effective gear. Usually gillnets were set in fish feeding ground. Gillnet mesh size is correlated negatively with the number of fish catch, the smaller mesh size might catch bigger amount of fish compared to the larger mesh sizes in catching fish. There are many types of gillnet operation, and variation in design in many ways depending on types of operation, the types of target species and its behavior. Because of simplicity in its design, construction, operation and low investment cost and its efficiency makes gillnet as preferred gear for the small scale fishermen. However most of the fish catch by the gillnets were small size and un-economical fish such as Indonesian leaffish. This might could be the reason the use of FAD in Ranau Lake.

The ecological implication of this result is that using the smaller size of gillnet might be non selective fishing gear. Therefore, it suggests to encourage using the larger gillnet mesh sizes (> 2.0 inch) as standard fishing gear to maintain the sustainable use of fish resources, especially in Ranau Lake (Muthmainnah et al., 2014). The larger of mesh size (> 2 inch) can catch the fewer fish but more economic such as Mozambique tilapia.

Increasing effort involves progressive reduction in the size of the species caught (Welcomme, 2001). Reduction in size is associated with changes in mortality rates, growth rates, production and number of species comprising the catch, so biomass and CPUE will be decreased. The higher CPUE for FAD fishing activity was much related to the fishing time than other fishing gears time. Gill net associated with FAD fishing activity is operated only during the early rainy season in littoral zone by a group of fishermen. Any fishermen used that gears, therefore there is no competition among fishermen. By using this gear, fishermen may catch more fish, and come up with relatively high CPUE. Fishermen would get in more effort for less catch in fishing ground. If a fisherman has only 1 gillnet, 1 harpoon, 1 net trap and 1 basket trap, Ranau Lake is estimated to produce $208 \mathrm{~kg}$ per year, valued at IDR 6,067,542.

Fishing in Ranau Lake is generally categorized into three types: family fishing (or small-scale), middle-scale fishing and large-scale fishing (or fishing lot) (Chee, 2005). Small scale fisheries practiced in every household around the Ranau Lake and it is usually carried out by family members using small gears, such as gillnet. Family fishing does not need license and it can take place all-year round. Considerable amount of catches are used for home consumption and all of households actively involved in fishing.

This type of fishery activity is often neglected in development planning because their contribution do not take into account social, economic and political influence (Thorpe \& Reid, 2005). Small scale fisheries engage in fishing with low level of capital and technology, low fishing potential as they use smaller, 
non-motorized fishing vessels (Sowman, 2006). At the same time, small scale fishers are confronted with the decline of catches in most freshwater resources.

Fish caught also sell as live fish or fresh fish in fishing point and in local market. By simple and traditional trading, they do not use weighing scale but count fish in a small container, unless for expensive species they sell in weight unit (kilogram). Due to this fact there is limited data about the income of fishing activity and fishermen do not know exactly how much their monthly income. It is estimated that the average income of fisherman of was about IDR $2,163,344$ per month. It is likely higher than the minimum regional salary in 2014 for South Sumatra worker that was arround IDR 1,825,000. It means that the fishermen in Ranau Lake reach standard Indonesian welfare.

Communities around the Ranau Lake who depend on aquatic resources will face several challenges in sustaining their livelihoods. The changes in the amount of rains will affect the ecological and environmental perspectives. The changes can also be induced by human activities, such as dam construction or deforestation that it will change on fisheries and aquatic resources such as the loss of spawning grounds and habitats, and decrease of catches. The activities will impact on fisheries catches, and thus decrease income to communities, is the involvement of illegal and destructive fishing gears. In Ranau Lake, the fish Mahseer had been the main fishing target in 1990's (Gaffar \& Utomo, 1991), however the fish seems be rarely caught by fishermen in this time. The fact was only one fish caught along year 2014 by experimental fishing. Other developments such as aquaculture, agriculture, tourism and housing, may also cause loss of flooded forest and degrade to the health of Ranau Lake aquatic ecosystems. The main economic benefits from the fisheries activities of Ranau Lake are scuring food and livehood particulary for local people. This study concluded that there are an alternative utilization of the Ranau Lake for a development of aquaculture site and tourism attraction.

\section{CONCLUSION}

Fish resources utilization in Ranau Lake was categorized as traditional and small scale fisheries using different selective fishing gears such gill net, harpoon, FAD and basket trap with the fish catch in average of $696.66 \mathrm{~g} /$ day; $205.03 \mathrm{~g} /$ day; $1,58406 \mathrm{~g} /$ day and $123.67 \mathrm{~g} /$ day, respectively. Fisherman income (IDR 2,163,300), means that the fishermen in Ranau Lake reach standard Indonesian welfare.

\section{ACKNOWLEDGEMENT}

The present study was funded by Ministry of Marine Affairs and Fisheries Republic of Indonesia throughout Research Institute for Inland Fisheries in 2014.

\section{REFERENCES}

Asiedu, B \& F.K.E. Nunoo. 2013. Alternative Livelihoods: A Tool for Sustainable Fisheries Management in Ghana. International Journal of Fisheries and Aquatic Sciences 2 (2): p. 21-28.

Chee, H.M. 2005. Aquatic resources valuation and policies for poverty elimination in the Lower Mekong Basin. DFID and World Fish Centre, Penang, Malaysia. 189 pp.

Deka, T.K., M. Kakati \& M.M. Goswami. 2001. Diversity of Wetland Fish and Its Impact on the Income of Fishermen Community of Assam. Journal of The Indian Fisheries Association. No. 28. p. 11-22.

Gaffar, A.K \& A.D. Utomo. 1991. Fishery resources of Komering River. Bulletin of Inland Fishery Research 10 (3). Agricultural Research and Development Agency. Center for Fishery Research and Development. Research Institute for Freshwater Fishery. Bogor. p. 1-6.

Kottelat, M., J.A. Whitten, N. Kartikasari \& S. Wiryoatmojo. 1993. Freshwater fishes of Western Indonesia and Sulawesi. Jakarta: Periplus Edition and EMDI Project Indonesia. 221 pp.

Makmur, S., D. Arfiati, G. Bintoro \& A.W. Ekawati. 2014. Morphological, meristic characteristics and mtDNA analysis of Hampala Fish (Hampala macrolepidota Kuhl \& Van Hasselt 1823) from Ranau Lake, Indonesia. Journal of Biodiversity and Environmental Sciences (JBES). Vol. 5, No. 2: p. 447-455.

Muthmainnah, D., Makri, Subagdja, D. Atminarso, S. Sawetri \& S. Makmur. 2014. Selectivity and effectiveness of different gillnet mesh sizes used in Ranau Lake of Sumatra. Journal of Biodiversity and Environmental Sciences (JBES) Vol. 5, No. 5: p. 82-89.

Samuel, S. Makmur \& N.K. Suryati. 2010. Karakteristik dan Pengelolaan Perikanan Danau Indonesia. Balai Penelitian Perikanan Perairan Umum. Palembang. 230 pp. 
Skurdal, J., T. Qvenild, T. Taugb \& E. Garnas. 1994. Can catch per unit effort data (CPUE) forecast yield in an exploited noble crayfish Astacus astacus L. Population: Biology, Culture and Management of the Noble Crayfish Astacus astacus L. p. 191203.

Sulastri, M. Badjoeri, Y. Sudarso \& M.S. Syawal. 1999. Physico-chemical and biological condition of Ranau Lake waters, South Sumatera. Research and Development Centre of Limnology, Indonesia Science Institute. Limnotek VI. p. 25-38.
Sowman, M. 2006. Subsistence and small-scale fisheries in South Africa: A ten-year review. Marine Policy, 30. p. 60-73.

Thorpe, A\& C. Reid. 2005. When fisheries influence national policy making: an analysis of the national development strategies of major fish producing nations in the world. Marine Policy, 29 (3): p. 211222.

Weber, M \& L.F. de Beaufort. 1913. The Fishes of the Indo-Australian. Archipelago. II.Malacopterygii, Myctophoidea, Ostariophysi: I. Siluroidea, Leiden, E.Brill,Ltd. 404 pp. 
Wegoye, J \& M. Kaidhiwa. 2001. Economic viability of fishing enterprises on Lake Victoria basin, Uganda to improve the income of conditions of artisanal fishermen.
Welcomme, R.L. 2001. Inland Water Fisheries: Ecology and Management. Fishing News Book. Oxford. $358 \mathrm{pp}$. 